\title{
MARKETING IN HIGHER EDUCATION: PROMOTING EDUCATIONAL SERVICES AND PROGRAMMES
}

\author{
Yulia STUKALINA* \\ Department of Humanities, Faculty of Management and Economics, \\ Transport and Telecommunication Institute, 1 Lomonosova Street, LV_1019, Riga, Latvia \\ *E-mail: stukalina.j@tsi.lv
}

\begin{abstract}
Purpose - the purpose of the article is to investigate current marketing and branding trends in higher education, and to discuss some popular marketing tools incorporated into the marketing strategy of a contemporary university. The relevance of the research topic is determined by the fact that managers working in higher education have to become more market-oriented as they are facing new challenges in an extremely competitive international environment.
\end{abstract}

Research methodology - the article is based on the analysis of theoretical literature and previous research on the topic, OECD and EU documents on the basic trends in higher education, and marketing plans of randomly chosen higher education institutions.

Findings - the analysis performed in the article has allowed the author to identify the main challenges experienced by contemporary universities in the agenda of promoting their educational services and programmes, and some novel marketing tools applied for enhancing the university's brand awareness and reputation.

Research limitations - the limitations of the study are mainly related to the research base, which includes a few higher education institutions, so future study with a broader research base is recommended to generalize the findings.

Practical implications - the research results may be useful for higher education managers responsible for developing a competitive marketing strategy of the university aimed at promoting their educational services and programmes.

Originality/Value - the research is based on the analysis of working marketing plans of some universities having good marketing traditions.

Keywords: university management, brand reputation, marketing tools.

JEL Classification: I29, M19.

Conference topic: (e.g.) Contemporary Organizations Development Management.

\section{Introduction}

In the context of significant changes occurring in higher education, modern universities compete for intellectual resources, students, national and global rankings, competition being an important force of their improvement. There are different contextual factors that influence the way universities develop their management and marketing policies. The most influential factors include a set of socio-economic, demographic, political, national (cultural) issues, as well as characteristics of students - their age, gender, socio-economic status, cultural background (OECD, 2018). So the relevance of the research topic is determined by the fact that managers working in higher education have to become more market-oriented as they are facing new challenges in the extremely competitive international environment.

The purpose of the paper is to investigate current marketing and branding trends in higher education and to discuss some popular marketing tools incorporated into the marketing strategy of a contemporary university. The paper is based on the analysis of theoretical literature and previous research on the topic, EU documents on marketing in higher education, and marketing plans of randomly chosen higher education institutions. The analysis performed in the paper has allowed the author to identify the main challenges experienced by universities on the agenda of promoting their educational services and programmes.

The results of the study suggest that a university's reputation is directly related to the capacity of its brand to meet stakeholders' expectations; in today's highly competitive environment, brand reputation management can be regarded as a key concern to most universities. 
The research results may be useful for managers responsible for developing a competitive marketing strategy of a university aimed at promoting their educational services and programmes.

\section{Marketing in a modern university in the agenda of considerable changes in the higher education sector}

\subsection{Current tendencies in higher education and their impact on marketing activities}

Modern higher education is influenced by various processes related to globalization, and at the same time, it exerts a strong influence over these processes (OECD, 2009). Higher education contributes to social and economic development by human capital creation, knowledge generation, exchange and maintenance, innovation, social, cultural and environmental development, as well as social cohesion (OECD, 2008; OECD, 2015; OECD, 2017).

The scope and significance of tertiary education have changed considerably; higher education sector is growing globally and participation is expanding; the proportion of international students is increasing; massification and internationalization of the sector are gaining speed (OECD, 2008; OECD, 2009: OECD, 2012; OECD, 2017). This all leads to the tdiversification of the student population.

Innovation leads to qualitative changes in the society as a whole, and in the country's educational system. Modernization of higher education is related to digitalization of tools and processes, which can foster teaching and learning' it is accompanied by enormous investments in ICT (OECD, 2016). Universities are becoming increasingly important contributors to the innovation process as they generate and transmit new ideas, being a source of human capital (League of European Research Universities, 2006). In this context, modernization of an academia calls for re-examination of educational practices and constant professional development of the academic and attending staff (European Parliament, Committee on Culture and Education, 2018); one of the main "design challenge" is to find a compromise between routine ("standardization") and innovation ("mutual adjustment") in an educational organization (OECD, 2010). The ability to assess innovation (how much teaching and learning practices are changing) is crucial for developing an improvement strategy in education; such knowledge reinforces the education knowledge base necessary for policy making (OECD 2010). Implementation of technology-supported pedagogic models is aimed at expanding the range of learning opportunities available to students (OECD, 2013), which is very important in the agenda of massification, internationalization and modernization of higher education.

Thus, current trends in tertiary education are associated with the following:

- Massification of higher education

- Internationalization of higher education

- Diversification of student population

- Modernization of higher education.

The above trends are closely connected with increasing collaboration and improving communication between universities, business and the society on the whole. Today, higher education institutions are concerned with establishing tight cooperation with all "social actors" to identify solutions for developing the most appropriate "products" (for example, study programmes, level of instruction, instruction tools, etc.), meeting both and social individual needs in terms of the labor market demands (Muhcina \& Moraru, 2016).

The next stage is then "promoting and marketing the product", which can be a serious challenge. In the highly competitive international environment, universities use all reasonable endeavors to strengthen their reputation (West, 2009) to increase enrolment and attract more talents. Higher education managers are now seeking for most efficient means to "bring into sync" their position with regard to internal strengths and weaknesses against external opportunities and threats (Stukalina, 2015), so contemporary academia must carefully consider the emerging tendencies and developments in the global education market. Some current trends in tertiary education and their impact on marketing management in universities are summarized in Table 1.

Table 1. Current tendencies in tertiary education and their impact on marketing management in academia (source: author's construction based on OECD documents)

\begin{tabular}{|l|l|}
\hline \multicolumn{1}{|c|}{ Current trends in higher education } & \multicolumn{1}{c|}{ Impact on marketing management in universities } \\
\hline Massification & $\begin{array}{l}\text { Customer uncertainty } \\
\text { Increased focus on stakeholder accountability }\end{array}$ \\
\hline Internationalization & $\begin{array}{l}\text { Customer uncertainty } \\
\text { Increased focus on international marketing }\end{array}$ \\
\hline Diversification of student population & $\begin{array}{l}\text { Customer uncertainty } \\
\text { Increased focus on diversification of programmes and services }\end{array}$ \\
\hline Modernization & $\begin{array}{l}\text { The shift from standardization to innovation } \\
\text { Increased focus on quality assurance }\end{array}$ \\
\hline
\end{tabular}


As seen from Table 1, there is a necessity to reconsider marketing strategies to be applied in a modern university in the agenda of significant changes occurring in the higher education area.

\subsection{Main trends in higher education marketing}

Marketing tools employed by educational organizations, in general, are similar to social marketing and services marketing, as the higher education market is influenced by social needs development (Filip, 2012). Modern universities are widely using marketing elements in their management; however, the scope of their marketing activities and the methods applied differ, as they depend much on various internal and external factors (Białon, 2015).

Nowadays, marketing environment is changing fundamentally owing to such forces as globalization, technological advances, deregulation, etc. (Kotler \& Keller, 2012). To be successful, marketing specialists must draw their attention to recent trends and developments in the marketing environment for making appropriate corrections to their marketing strategies (Kotler \& Keller, 2016).

As the above forces influence the international education market, the accompanying changes in the global higher education have a significant impact on the way marketing strategies are developed and implemented in contemporary universities. In the process, marketing managers apply different marketing models, including the so-called "Marketing Mix Model", which is also applicable for higher education (Kotler \& Fox, 1985; Kotler \& Fox, 1995).

Marketing strategies of academia are aimed at providing active support for the implementation of overall strategies created for improving the university's position in the global education market (Białoń, 2015). Since academia management faces the need to attract an enhanced and diverse student population, successful branding and marketing are becoming very important activities; universities are also hiring marketing specialists from the business area and are investing more money in improving their brands (Hanover Research, 2014). ble 2 .

Some present-day trends in higher education marketing and the related marketing objective are presented in Ta-

Table 2. Main trends in higher education marketing and possible outcomes

(source: author's construction based on Hanover Research (2014))

\begin{tabular}{|l|l|}
\hline \multicolumn{1}{|c|}{ Trend } & \multicolumn{1}{c|}{ Outcome } \\
\hline Increased investment in building a strong institutional & Solid brand identity \\
\hline $\begin{array}{l}\text { Increased investment in human capital (both academic } \\
\text { and attending staff) }\end{array}$ & $\begin{array}{l}\text { Improved quality of educational programmes } \\
\text { and services }\end{array}$ \\
\hline Integration of "corporate mentality" into a university culture & Transformed "business model" \\
\hline $\begin{array}{l}\text { Increased use of the personal approach to every } \\
\text { prospective student }\end{array}$ & Increased market share (increased enrolment) \\
\hline Increased use of ICTs in marketing processes & Improved brand engagement \\
\hline Ongoing use of traditional marketing strategies & $\begin{array}{l}\text { Improved "product" (educational programmes } \\
\text { and services) awareness }\end{array}$ \\
\hline
\end{tabular}

As one can see from Table 2, modern trends in higher education marketing necessitate developing a competitive marketing strategy focused on building and maintaining a strong institutional brand, which represents a unique and recognizable symbol.

\section{Marketing strategies developed for promoting educational programmes and services}

\subsection{Marketing objectives as reflected in the marketing plans of contemporary universities}

In the marketing environment, marketing specialists consider "brand, industry, form, and generic competition" (Kotler \& Keller, 2012).

Marketing strategy usually embraces two basic elements (Chernev, 2014):

- The target market (operational context, target audience, educational organization itself, collaborators and competitors)

- Value proposition.

The choice of marketing strategy in a university depends on a number of factors such as the situation in the educational market and the state of marketing knowledge from the period under research; the results of the marketing environment analysis will include different "scenarios" for improving a higher education institution (Białon', 2015). The results of the marketing environment analysis are reflected in the marketing strategy of a university. This document incorporates long-term goals based on the strategic goals specified in the overall strategy, various techniques and tools to be applied for accomplishing the goals (Białon, 2015). Long-term goals are supported by a set of objectives. The 
objectives formulated together with long-term goals should be more concrete and more clearly defined (Thompson \& Strickland, 2003).

Some marketing objectives formulated by modern universities on the basis of the marketing environment analysis are presented in Table 3.

Table 3. Marketing objectives based on the results of the marketing environment analysis (source: author's construction based on the analysis of Marketing Plans of University of Arizona/College of Engineering (2016), Wilamette University (2015), Missouri State University (2013))

\begin{tabular}{|l|l|}
\hline \multicolumn{1}{|c|}{ Type of analysis } & \multicolumn{1}{c|}{ Marketing objectives based on the obtained results } \\
\hline Situational analysis & $\begin{array}{l}\text { Increasing overall visibility and attractiveness by improving } \\
\text { national and international rankings }\end{array}$ \\
\hline Competitive analysis & Strengthening the brand by emphasizing key brand distinctions \\
\hline SWOT analysis & $\begin{array}{l}\text { Increasing positive awareness of the brand by developing } \\
\text { a more effective system of internal and external communications }\end{array}$ \\
\hline
\end{tabular}

As seen from the above table, contemporary academias consider creating and maintaining a successful institutional brand to be key to their success.

As a positive brand image and reputation have a direct impact on the consumer behavior (Kotler and Keller, 2016), a strong brand would confirm its credibility in the international education market in the agenda of promoting educational services and programmes.

\subsection{Building a strong institutional brand}

In business, brand is defined as a set of exclusive characters and associations identifying an offering and creating value beyond the basic aspects of this offering (Chernev, 2014). Brands are supposed to deliver a high level of assurance to customers, the brand's value being directly related to its ability to gain a unique and positive meaning for them (Panda, 2007). Branding is directly associated with differentiating the product or service from competitors (Kotler \& Keller, 2016). Brand symbolizes all information about a service or product (Keller, 2003).

A strong brand is important, as it allows an organization discovering new opportunities through extension and compensating for environmental threats. Many serious challenges that universities encounter today have caused the emphasis to be placed on the branding of higher education institutions (Woyo et al., 2014). Modern universities are now becoming more "entrepreneurial". Entrepreneurialism in higher education can be regarded as the ability to adapt to an uncertain external environment (Shattock, 2009).

With enhanced global competition in the educational market, the notion of branding is widely used in higher education. A brand in this sector includes tangible and intangible components. They may comprise the following (Valitov, 2014):

- University attributes

a) state accreditation of the academia or educational programmes;

b) inteternational accreditation of educational programmes;

c) qualification of the academic staff (e.g. percentage of teachers with $\mathrm{PhD}$ degree, the number of foreign professors);

d) financial characteristics (e.g. tuition fee, available scholarships and grants);

e) available facilities (e.g. location, university environment);

f) technology (ICTs)

- University image

a) diploma prestige and value;

b) assured employment;

c) history of a university;

d) achievements of graduates, etc.

- University brand value.

Some marketing strategies, which are aimed at building and maintaining a strong institutional brand, are described in Table 4.

Marketing strategies developed on the basis of the performed marketing environment analysis should be supported by a set of tactics. The tactics embody the main marketing decisions representing the marketing strategy (Chernev, 2014). 


\subsection{Enhancing the awareness of the university's educational services and programmes}

Brand awareness is regarded as a precondition for the market success of brands (Moisescu, 2009). Brand awareness cultivates people's ability to identify the brand to an extent that they will wish to "make a purchase" (Kotler \& Keller, 2016).

Brand awareness includes awareness of the tangible and intangible brand constituents. In higher education, these components embrace, among other things, educational services and programmes. The tactics used in the context of enhancing awareness of university services and programmes are grouped according to the selected marketing strategy.

Table 4. A few marketing strategies aimed at building a strong institutional brand (source: author's construction based on Missouri State University Marketing Plan (2013))

\begin{tabular}{|l|l|}
\hline \multicolumn{1}{|c|}{ Marketing strategy } & \multicolumn{1}{c|}{ Related activities } \\
\hline Renewing the look of the brand & Recruiting design professionals from or outside the university \\
\hline $\begin{array}{l}\text { Sharing the origin of the brand within the campus } \\
\text { community }\end{array}$ & $\begin{array}{l}\text { Developing campaigns aimed at increasing brand awareness among } \\
\text { faculty and students }\end{array}$ \\
\hline $\begin{array}{l}\text { Creating the brand through the success of educational } \\
\text { programmes }\end{array}$ & Developing unique programmes with successful placement rates \\
\hline Cultivate the brand naturally through the campus & $\begin{array}{l}\text { Developing a propagation plan and using social media for its imple- } \\
\text { mentation }\end{array}$ \\
\hline Accessing the brand for everyday needs & $\begin{array}{l}\text { Organizing marketing workshops with representatives from differ- } \\
\text { ent departments }\end{array}$ \\
\hline $\begin{array}{l}\text { Incorporating messaging that includes the university's } \\
\text { competitive advantages }\end{array}$ & $\begin{array}{l}\text { Developing communication strategies focused on unique academic } \\
\text { opportunities provided by the university }\end{array}$ \\
\hline
\end{tabular}

The tactics may include the following focus areas and related initiatives, as reflected in the Wilamette University Marketing Plan (2015).

1. Concentrating on key brand distinctions

- Organize a regular group of university communicators for updates on current marketing communications

- Build a dynamic institutional website

- Perform an audit of current social media channels and create an appropriate digital media strategy

- Make a healthy editorial calendar for the website and main publications.

2. Creating a cohesive institution-wide system of communications that integrates updated recruitment, admission and enrolment communications tools

- Develop an online content integrating storage of "hero" stories about the university

- Develop an "interactive newsroom" including current news, events, media fact sheets and a faculty expert list

- Create new digital content with search engine optimization possibilities

- Develop a comprehensive e-mail marketing system for tracking contacts, e-newsletters and segment audiences

- Develop digital content containing logos, photographs, social media icons, templates, style guides

- Schedule regular marketing "skill-development" workshops and seminars

- Develop updated print and online materials for undergraduate admissions

- Improve e-mail marketing processes for undergraduate students.

3. Positioning the university as a leading institution by means of an effective media relations strategy

- Create a "faculty experts list" and send it to media

- Organize annual media training sessions for faculty and administrators.

4. Developing special communication plans for the graduate programs

- Refreshing content for direct marketing campaigns

- Create original view books and admit packages

- Work out direct marketing strategies for particular university colleges.

5. Increasing attraction among supporters of the university

- Cooperate with alumni and parents on building an updated brand identity

- Develop reliable messaging across the university

- Improve a brand image through annual events

- Strengthen the links with the community through the "Institute of Continous Learning".

6. Focusing on repositioning the university in the frame of the fundraising campaign.

7. Designing an institutional "visibility and awareness" campaign

- Produce institutionally specific radio, print, digital and outdoor/display advertising tools

- Assess the effectiveness of these initiatives and make modifications when necessary. 
The above initiatives should all carry a few specific key messages related to the university's brand. These key messages are directed to the target audiences (stakeholders). The stakeholders may involve current and prospective students, their parents, alumni, staff, sponsors, employers, media, government agencies, non-governmental organizations, etc.

\section{Measuring the success of the university's marketing plan}

\subsection{Marketing metrics}

Assessment of marketing performance is considered to be an essential supplement to marketing activities, marketing performance being defined as the ability to accomplish marketing objectives (Solcansky \& Simberova, 2010). A marketing plan should contain concrete outcomes to track the progress of its implementation. For assessing progress, different metrics can be used, so the outcomes specified in the marketing plan can take different forms.

The term "metric" may be defined as tools quantifying a "trend, dynamic or characteristic" (Reibstein, Farris, Bendle, \& Pfeifer, 2006). According to Kotler et al. (2009), marketing metrics include an assortment of performance measures assisting companies to measure and better understand their marketing performance.

The so-called internal market metrics are associated with various factors such as active innovation support, relative employee satisfaction and their enthusiasm for learning, etc.; the external market metrics include financial measures, but brand equity also requires various non-financial measures, when the "adjustment is conceptual, not in cash" (Ambler, 2000).

Some popular external market metrics include (ibid.):

- Total number of customers

- Consumer satisfaction

- Customer loyalty

- Number of complaints

- Market share (volume or value)

- Perceived quality

- Awareness

- Distribution

- Availability.

It should be mentioned that the above metrics are designed in different areas in a different way depending on the characteristics of the given area (Ambler, 2000). So in the higher education sector, metrics may take a variety of forms, due to differences in the nature of academias, as well as in their institutional objectives (Pollard et al., 2013).

\subsection{Success measurements as short-term, intermediate-term and long-term outcomes}

Some universities use such success measurements that as outcome indicators. These indicators put the emphasis on the dimensions, which are related to value (Mone, Pop, \& Racolţa-Paina, 2013). Below are listed a selection of outcome indicators itemized in the Missouri State University Marketing Plan (2013):

1. Short-term outcomes (six months - one year):

- Established marketing advisory committee;

- Refreshed and revised brand identity;

- Qualitative study for benchmarking new brand assets;

- Shared vision of the university's promotional strategy.

2. Intermediate term outcomes (one-two years):

- Established communications committee;

- New brand guide and corresponding templates;

- Increased acceptance rate of brand identity;

- Novel paid-media strategy;

- Special recruit students and start student blogger program;

- New recommendations for recruitment events and publications;

- Implementation of revolutionary marketing ideas.

3. Long-term outcomes (more than two years):

- Increased student enrolment;

- Study for benchmarking changes in brand awareness;

- Increased market share in crucial educational markets;

- Increased engagement of alumni and sponsors;

- Positive change in brand awareness. 


\subsection{Success measurements as KPI - key performance indicators}

Other universities express success measurements in terms of key performance indicators (KPI). Key performance indicators designate what must be done for increasing organizational performance radically; they symbolize a number of measures that focus on the aspects, which are the most important for the success of the company (Parmenter, 2009).

Parmenter distinguishes seven characteristics of key performance indicators (ibid.):

- They include non-financial measures;

- They are measured frequently;

- They are utilized by senior management;

- All staff have to understand and use them;

- The responsibility is assigned to the individual or team;

- They must influence core critical success factors;

- They must influence other measures positively.

Thus, in some marketing plans, marketing metrics can take the form of KPI. Main key performance indicators specified in the Communications and Marketing Plan of the University of Manchester (2015) are presented in Table 5.

Table 5. Key performance indicators as specified in the university's marketing plan

(source: Communications and Marketing Plan of the University of Manchester (2015))

\begin{tabular}{|c|c|}
\hline KPI category & Key performance indicator \\
\hline \multirow{4}{*}{ 1. KPI linked to outcomes } & Print and broadcast media coverage \\
\hline & Social media engagement (e.g. Facebook, Twitter) \\
\hline & Social media referrals to the website \\
\hline & Amount of unique website users \\
\hline \multirow{6}{*}{ 2. KPI linked to pride and engagement } & Staff - proud to be members of the university \\
\hline & Staff - satisfied with the system of communications \\
\hline & Students - proud to study at the university \\
\hline & Students - satisfied with the system of communications \\
\hline & Alumni - proud to be graduates of the university \\
\hline & Alumni - satisfied with the system of communications \\
\hline \multirow{3}{*}{ 3. KPI linked to reputation } & Position in US News Global Reputation Survey \\
\hline & Position in the national media survey \\
\hline & Position in the world University Rankings \\
\hline
\end{tabular}

It should be noted that in different universities, they use different marketing metrics dependent on many factors:

- type of ownership (private or state);

- location;

- size;

- offered degrees and educational programmes;

- university services and facilities;

- educational experience;

- marketing experience;

- more (less) focus on research and innovation;

- staff engagement in the marketing processes;

- student engagement in the marketing processes;

- level of ICTs integration in the learning process, etc.

\section{Conclusions}

The analysis carried out in this paper has allowed the author to make the following conclusions.

In the higher education sector, more emphasis is now placed on marketing. Managers working in the field have to use a more market-oriented approach, which is determined by the challenges they face today. The shift towards marketing is closely associated with emerging tendencies in the area: massification, internationalization of higher education, and modernization of higher education, as well as diversification of student base. This makes modern academias to create a competitive strategy aimed at achieving academic success and attracting best talents in the extremely competitive higher education market. 
The trends developed within higher education marketing require universities to use marketing elements in their management. Universities have to reconsider their previous strategies and reorient from the reactive to the more proactive approach. Considerable changes in international higher education have a significant impact on the way marketing strategies are created and implemented in contemporary academia. Modern marketing strategies are now focused on building and maintaining a strong institutional brand; a strong brand would confirm the credibility of academia in the global education market. Brand awareness, including awareness of the tangible and intangible brand constituents (educational services and programmes), might inspire brand affinity, so it vital to enhance the awareness of these services and programmes. There are various tactics applied in the context of increasing brand awareness, which is grouped according to selected marketing strategy; they involve a set of initiatives that must carry a few specific key messages addressed to all stakeholders (target audiences).

Evaluation of marketing activities is an essential part of the marketing strategy implementation. In higher education, different marketing metrics (success measurements) can be used for tracking progress in the marketing area; they can be quantitative and qualitative by nature. Different academias employ different metrics depending on a number of factors, being closely related to the marketing objectives stated in the marketing plan of a particular university.

The limitations of the study are mainly related to the research base, which includes a few higher education institutions, so future study with a broader research base is recommended to generalize the findings. Empirical research based on the collection and analysis of primary data in the field is also advisable.

\section{Disclosure statement}

The author does not have any competing financial, professional, or personal interests from other parties.

\section{References}

Ambler, T. (2000). Marketing metrics. Business Strategy Review, 11, 59-66. https://doi.org/10.1111/1467-8616.00138

Białoń, L. (2015). Creating marketing strategies for higher education institutions. Marketing of Scientific and Research Organizations, 18(4), 129-146. https://doi.org/10.14611/minib.18.04.2015.13

Chernev, A. (2014). Strategic Marketing Management (8th ed.). USA: Cerebellum Press.

Communications and Marketing Plan of the University of Manchester (2015). Summary document 2015-2018. Retrieved from http://documents.manchester.ac.uk/display.aspx?DocID=25256

European Parliament, Committee on Culture and Education (2018). Report on modernisation of education in the EU. Retrieved from http://www.europarl.europa.eu/sides/getDoc.do?type=REPORT\&reference=A8-2018-0173\&language=EN

Filip, A. (2012). Marketing theory applicability in higher education. In Procedia of Social and Behavioral Sciences, 469, 912-916. https://doi.org/10.1016/j.sbspro.2012.05.223

Hanover Research. (2014). Trends in higher education marketing, recruitment, and technology, March 2014. Retrieved from https://www.hanoverresearch.com/media/Trends-in-Higher-Education-Marketing-Recruitment-and-Technology-2.pdf

Keller, L. K. (2003). Building, measuring, and managing brand equity (2nd ed.). New Jersey: Prentice Hall.

Kotler, P., Keller, K. L., Brady, M., Goodman, M., \& Hansens, T. (2009). Marketing management. London: Pearson Education Limited.

Kotler, Ph., \& Fox, K. (1985). Strategic marketing for educational institutions. N. J.: Prentice-Hall.

Kotler, P., \& Fox, K. (1995). Strategic marketing for educational institutions (2nd ed.). N. J.: Prentice-Hall.

Kotler, Ph., T., \& Keller, K. L. (2012). Marketing Management (14th ed.). UK: Pearson

Kotler, Ph., T., \& Keller, K. L. (2016). Framework for Marketing Management (6th ed.). UK: Pearson

League of European Research Universities (2006). Universities and innovation: the challenge for Europe (2006). Leuven, Belgium. Retrieved from https://www.leru.org/files/Universities-and-Innovation-the-Challenge-for-Europe-Full-paper.pdf

Missouri State University Marketing Plan (2013). Retrieved from https://www.missouristate.edu/assets/marcom/MSU_Marketing_Plan_11-07-2013.pdf

Moisescu, O. I. (2009). The importance of brand awareness in consumers' buying decision and perceived risk assessment. Management and Marketing, 7(1), 103-110. EUC: Editura Universitaria Craiova.

Mone, S.-D., Pop, M. D., \& Racolţa-Paina, N.-D. (2013). The "what" and "how" of marketing performance management. Management and Marketing Challenges for the Knowledge Society, 8(1), 129-146.

Muhcina, S., \& Moraru, A.-D. (2016). Educational marketing challenges - universities and graduates' employment: A case study. Annales Universitatis Apulensis Series Oeconomica, 18(1), 27-34.

OECD. (2008). Tertiary Education for the Knowledge Society: Volume 1: Special Features: Governance, Funding, Quality; Volume 2: Special Features: Equity, Innovation, Labour Market, Internationalisation. OECD Paris. Retrieved from http://www.oecd.org/education/skills-beyond-school/41266690.pdf

OECD. (2009). Higher education to 2030, Volume 2: Globalisation. Executive summary. OECD Paris. Retrieved from https://www.oecd.org/education/ceri/44101074.pdf . https://doi.org/10.1787/9789264075375-en

OECD. (2010). Innovative workplaces: Making better use of skills within organisations. OECD Publishing. Retrieved from http://www.oecd.org/sti/inno/46458265.pdf . https://doi.org/10.1787/9789264095687-en 
OECD. (2012). Education at a Glance 2012: Highlights. OECD Publishing. Retrieved from http://www.oecd.org/education/highlights.pdf. https://doi.org/10.1787/eag_highlights-2012-en

OECD. (2013). Sparking Innovation in STEM Education with Technology and Collaboration. OECD Publishing. Retrieved from http://www.oecd.org/education/ceri/OECD_EDU-WKP(2013)_\%20Sparking\%20Innovation\%20in\%20STEM\%20education.pdf

OECD. (2015). Education at a Glance 2015: OECD Indicators. OECD Publishing. Retrieved from https://www.oecd-ilibrary.org/docserver/eag-2015-en.pdf?expires=1550338112\&id=id\&accname=guest\&checksum=B3AA46DCBEE A954352AA3910D49973D6

OECD. (2016). Innovating Education and Educating for Innovation: The power of digital technologies and skills. OECD Publishing. Retrieved from http://www.oecd.org/education/ceri/GEIS2016-Background-document.pdf. https://doi.org/10.1787/9789264265097-en

OECD. (2017). Benchmarking higher education system performance: Conceptual framework and data, Enhancing Higher Education System Performance. OECD Paris. Retrieved from https://www.oecd.org/education/skills-beyond-school/Benchmarking\%20Report.pdf

OECD. (2018). Education at a Glance 2018: OECD Indicators. OECD Paris. Retrieved from https://read.oecd-ilibrary.org/education/education-at-a-glance-2018_eag-2018-en\#page3

Panda, T. K. (2007). Marketing management (2nd ed.). New Delhi: Excel Books.

Parmenter, D. (2009). Key performance indicators: Developing, implementing and using winning KPIs. New Jersey: John Wiley and Sons, Inc.

Pollard, E., Williams, M., Williams, J., Bertram, Ch., Buzzeo, J., Drever, E., Griggs, J, \& Coutinho, S. (2013). How should we measure higher education? A fundamental review of the Performance Indicators. Part Two: The evidence report. Institute for Employment Studies/ National Centre for Social and Economic Research. Retrieved from https://dera.ioe.ac.uk/ 18967/2/2013_ukpireview2.pdf

Reibstein, D., Farris, P., Bendle, N., \& Pfeifer, P. (2006). Marketing Metrics: 50+ Metrics Every Executive Should Master. Wharton School Publishing, Upper Saddle River.

Shattock, M. (2009). Entrepreneurialism and organizational change in higher education. In M. Shattock (Ed.), Entrepreneurialism in Universities and the Knowledge Economy: Diversification and Organisational Change in European Higher Education (pp. 1-8). UK: Society for Research into Higher Education \& Open University Press.

Solcansky, M., \& Simberova, I. (2010). Measurement of marketing effectiveness. Economics and Management, 15, 755-759.

Stukalina, Y. (2015). Management in higher education: Thinking and planning more strategically. Journal of Business Management, 10, $70-79$.

Thompson, A., \& Strickland, A. J. (2003). Strategic Management. Concepts and Cases (13th ed.). Boston: McGraw-Hill.

University of Arizona (College of Engineering) Marketing, Branding and Communications Plan (2016). Retrieved from https://docplayer.net/3451467-University-of-arizona-college-of-engineering-marketing-branding-and-communications-plan. html

Valitov, S. M. (2014). University brand as a modern way of winning competitive advantage, In Procedia - Social and Behavioral Sciences, 152, 295-299. https://doi.org/10.1016/j.sbspro.2014.09.198

West, P. W. A. (2009). A Faustian Bargain? Institutional Responses to National and International Rankings. Higher Education Management and Policy: Journal of the Programme on Institutional Management in Higher Education, OECD Paris, 21(1), 9-18. https://doi.org/10.1787/hemp-v21-art1-en

Wilamette University Institutional Marketing Plan. (2015). Retrieved from http://willamette.edu/committees/imc/willamette-imp2015-2018.pdf

Woyo, E., Hlulani Obert, H., \& Frank, G. (2014). Brand Reputation Management within the Higher Education Sector: A Review of the Literature on Higher Education Brand Reputation Management. International Research Journal of Marketing, 2(1), 1-8. https://doi.org/10.12966/irjm.02.01.2014 